\title{
KETERSEDIAAN ZAT GIZI MAKRO PADA MENU MAKAN SIANG YANG DISAJIKAN DI SEKOLAH DASAR ISLAM TERPADU (SDIT) INSAN MULIA KEDIRI TERHADAP KECUKUPAN ZAT GIZI ANAK SEKOLAH
}

\author{
Nur Fathin Sholihah ${ }^{1}$, AASP Chandradewi ${ }^{1 *}$, Ni Ketut Sri Sulendri ${ }^{1}$ dan Luh Suranadi ${ }^{1}$, \\ ${ }^{1}$ Jurusan Gizi, Poltekkes Kemenkes Mataram \\ Jl. Prabu Rangkasari, Sandubaya, Kota Mataram, Nusa Tenggara Barat 83232, Indonesia \\ *Korespondensi : Email: chandradewi168@gmail.com
}

\begin{tabular}{l}
\hline Article Info \\
\hline Article history: \\
Received January $14^{\text {th }}, 2021$ \\
Revised February $21^{\text {th }}, 2021$ \\
Accepte March $25^{\text {th }}, 2021$ \\
\hline
\end{tabular}

Keyword:

Local food, Fiber content; Organoleptic properties; Snack bar

\section{Keyword:}

Kandungan serat; Pangan local; Sifat organoleptic; Snack bar

\begin{abstract}
Background : School-age children need balanced nutrition to increase concentration and receive knowledge so that they can support learning activities. For this reason, it is necessary to provide lunch so that adequate nutrition is met. The purpose of this study was to analyze the availability of macro nutrients on the lunch menu presented in Insan Mulia Kediri's integrated Islamic elementary school (SDIT) towards the nutritional adequacy of school children.
\end{abstract}

Method : This type of research used observational analytics from time including crosscestional research Methods of data collection using interviews, observation, and documentation. Sampling uses systematic random sampling technique with a sample of 216 students from a population of 442 students. Processing data using a distribution table and then presented in the form of tables and bar charts.

Results : The provision of lunch menus by catering for 4 days, namely the average availability of macro-energy nutrients of 573 kcal, protein 15.3 grams, fat 7.0 grams, and carbohydrates 111.6 grams. The availability of energy is based on the adequacy of school children in more categories as many as 98 people (45.4\%) and in the less category as many as 64 people (29.6\%), Protein in the category of more than 101 people (46.8\%), fat availability in the category there are 214 people (99.1\%), and the availability of carbohydrates in the category is 151 people (69.9\%).

Conclusion : In general, the average availability of energy, protein, fat has fulfilled the adequacy of nutrition except fat. There is a significant relationship between the availability of macro nutrients and the nutritional adequacy of school children, which is 0.00 ( $p<0.05)$, so that the higher availability of macro nutrients is provided, the higher the nutritional adequacy of school children can be fulfilled.

\section{PENDAHULUAN}

Masalah gizi pada anak sekolah dasar saat ini masih cukup tinggi. Berdasarkan data Riset Kesehatan Dasar (Riskesdas) tahun 2013, prevalensi nasional Anak Usia Sekolah (5-12 tahun) kurus adalah 11,2\%. Prevalensi kurus (menurut IMT/U) Nusa Tenggara Barat yaitu 7,2\%. Selain masalah anak kurus terdapat juga masalah prevalensi anak gemuk secara nasional yaitu anak usia sekolah (5-12 tahun) gemuk 18,8\%.Pada penelitian Purnamasari dkk tahun (2013) pada anak sekolah kelas IV menunjukkan 9,9\% anak sekolah mengalami kurus. 
Berdasarkan data hasil Pemantauan status gizi tahun 2016 prevalensi nasional Anak Usia Sekolah (5-12 tahun) kurus sebanyak 7,8\% dan sangat kurus 2,7\%. Kemudian pada tahun 2017 Anak Usia Sekolah yang kurus menurun menjadi 7,5\% sedangkan anak usia sekolah yang sangat kurus meningkat 3,4\%. Prevalensi anak sekolah pada tahun 2016 sangat kurus dan kurus berdasarkan indeks IMT/U di Nusa tenggara Barat dengan prevalensi sangat kurus 3\% dan kurus 9\%. Pada tahun 2017 anak usia sekolah kurus menurun menjadi $8,7 \%$ namun meningkat pada anak yang sangat kurus menjadi $4 \%$.

Anak kelompok usia sekolah (6-12 tahun) termasuk salah satu kelompok yang rentan mengalami masalah gizi yaitu kekurangan energi protein. Riset Kesehatan Dasar 2013 menunjukkan sekitar 44,4\% anak sekolah, tingkat konsumsi energinya kurang dari $70 \%$ dari Angka Kecukupan Gizi (AKG) dan terdapat sebanyak $59,7 \%$ anak usia sekolah tingkat konsumsi proteinnya kurang dari $80 \%$ berdasarkan AKG. Berdasarkan penelitian Samilar, Budi Setyawati dan Anies Irawati Proporsi anak usia sekolah yang defisit energi secara nasional 83,9 persen, sebanyak 64,4 persen defisit energi tergolong berat ( $<70 \% \mathrm{AKE})$, dan defisit protein sebesar 64,2 persen, sebanyak 17,8 persen defisit protein tergolong berat ( $<70 \% \mathrm{AKP})$.

Anak usia sekolah membutuhkan asupan zat gizi yang seimbang untuk menunjang kegiatan belajar di sekolah. Karena asupan zat gizi akan mempengaruhi daya kosentrasi dan menerima dan menyerap setiap ilmu yang didapat di sekolah. (Depkes,2015).

Pemberian makanan yang bergizi utamanya dapat menjamin pertumbuhan dan perkembangan anak. Anak sekolah berada di sekolah dari jam 07.00 wita sampai 14.00 wita. Pada siang hari waktunya makan siang, sedangkan anak - anak masih berada di sekolah, jadi diperlukan penyelenggarakan makan siang di sekolah untuk memenuhi kecukupan gizi anak sekolah (Utami, Adina Tri 2013). SDIT Insan Mulia Kediri ini adalah salah satu sekolah dasar yang menyelenggarakan makan siang untuk anak

sekolah. Hasil obesrvasi awal penyediaan menu makan siang di SDIT Insan Mulia Kediri terdapat jenis sumber energi yang yaitu nasi dan mie goreng, tidak ada protein nabati, dan sayur hanya 5\% dari anjuran konsumsi sayur dari Permenkes Nomor 41 Tahun 2014 tentang Pedoman Gizi Seimbang konsumsi sayuran sejumlah 250 gram sayur.

Berdasarkan latar belakang tersebut maka peneliti tertarik untuk melakukan penelitian tentang "Analisis Ketersediaan Zat Gizi makro Pada Makan Siang Yang Disajikan Di Sekolah Dasar Islam Terpadu Insan Mulia Kediri Terhadap Kecukupan Zat Gizi Anak sekolah"

\section{METODE PENELITIAN}

\section{Desain Penelitian}

Penelitian ini merupakan penelitian Observasional analitik, dari waktu termasuk penelitian crosscestional yaitu penelitian yang pengukuran variabel - variabelnya dilakukan hanya satu kali pada satu saat

\section{Besar Sampel}

Pengambilan sampel dilakukan dengan teknik systematic random sampling. Sampel diambil dengan membuat daftaranggota populasi kemudian membagi dengan jumlah sampel yang diinginkan, hasilnya adalah $k$, maka yang menjadi sampel penelitian ini adalah setiap kelipatan $k$ tersebut. (Notoatmojo,2012). Dapat dihitung sebagai berikut :

$$
-\mathrm{k}=\stackrel{N}{\vec{n}}=\stackrel{442}{54}=8
$$

dimana $\mathrm{N}=$ Jumlah Populasi dan $\mathrm{n}$ = Jumlah sampel. Berdasarkan data yang diperoleh besar sampel sebanyak 54 orang siswa/hari. Pengambilan sampel dilakukan 54 orang siswa/hari. Penelitian dilakukan selama 4 hari. Jadi, besar sampel dalam penelitian ini adalah 216 Sampel.

\section{Cara Analisis Data}

Analisis ketersediaan zat gizi pada menu makan siang berupa nasi, lauk hewani, lauk nabati, dan sayur yang disajikan dengan cara menimbang berat mentah bahan makanan kemudian dihitung nilai gizi menggunakan Nutrisurvey. Hasil disajikan dalam satuan sumber energi (kkal), protein (gram), lemak (gram), dan Karbohidrat (gram) lalu dibandingkan dengan kecukupan gizi anak sekolah.Pengolahan data menggunakan tabel distribusi kemudian dipresentasikan berupa tabel dan diagram batang. 
HASIL PENELITIAN

Karakteristik Sampel

Distribusi sampel berdasarkan umur responden

Tabel 1. Distribusi Frekuensi Responden berdasarkan umur

\begin{tabular}{lcc}
\hline \multicolumn{1}{c}{ Umur } & n & \% \\
\hline 6 tahun & 6 & $3 \%$ \\
7-9 tahun & 118 & $55 \%$ \\
10-12 tahun & 92 & $43 \%$ \\
\hline Jumlah & $\mathbf{2 1 6}$ & $\mathbf{1 0 0 \%}$ \\
\hline Sumber : Data Primer 2019 & &
\end{tabular}

Tabel 2. Distribusi Frekuensi berdasarkan jenis kelamin

\begin{tabular}{lcc}
\hline \multicolumn{1}{c}{ Umur } & $\mathbf{n}$ & $\mathbf{\%}$ \\
\hline Laki-laki & 111 & 51 \\
Perempuan & 105 & 49 \\
\hline Jumlah & $\mathbf{2 1 6}$ & $\mathbf{1 0 0}$ \\
\hline Sumber : Data Primer 2019 & &
\end{tabular}

\section{Biaya Menu Makan Siang}

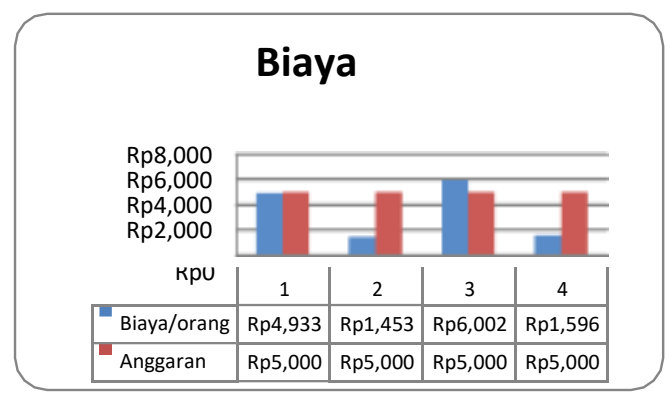

Diagram 1. Biaya menu makan siang

Pada diagram 1 di atas, diketahui bahwa biaya yang tertinggi dikeluarkan untuk penyelenggaran makanan yaitu pada hari ketiga Rp 6.002 dan paling rendah pada hari kedua sebesar Rp 1.453.

\section{Pola Menu}

Tabel 3. Pola menu di SDIT Insan Mulia Kediri

\begin{tabular}{|c|c|c|c|c|}
\hline \multirow{2}{*}{ Menu } & \multicolumn{4}{|c|}{ Hari Ke- } \\
\hline & 1 & 2 & 3 & 4 \\
\hline $\begin{array}{l}\text { Makanan pokok } \\
(\mathrm{Mp})\end{array}$ & Mp & Mp & Mp & Mp \\
\hline Lauk hewani (Lh) & $\mathrm{Lh}$ & & $\mathrm{Lh}$ & \\
\hline Lauk nabati (Ln) & - & Ln & $\mathrm{Ln}$ & Ln \\
\hline Sayur (S) & - & $\mathrm{S}$ & - & $S$ \\
\hline $\begin{array}{l}\text { Makanan pokok } \\
(\mathrm{Mp})\end{array}$ & Mp & $\mathrm{Mp}$ & Mp & Mp \\
\hline Pola Menu & $\mathbf{M p}+\mathbf{L h}$ & $\mathrm{Mp}+\mathrm{Ln}+\mathrm{S}$ & Mp+Lh+Ln & $\mathrm{Mp}+\mathrm{Ln}+\mathrm{S}$ \\
\hline
\end{tabular}

Sumber : Data Primer 2019

Dari tabel 3. diketahui Lauk hewani tidak terdapat pada hari kedua dan keempat. Tidak terdapat sayur pada siklus menu hari pertama dan ketiga. 
Ketersediaan zat gizi menu makan siang yang disediakan di SD IT Insan Mulia Kediri Tabel 4. Ketersediaan Zat Gizi Pada Siklus Menu4 Hari

\begin{tabular}{ccccc}
\hline \multirow{2}{*}{ Hari Ke- } & \multicolumn{4}{c}{ Ketersediaan Zat Gizi } \\
\cline { 2 - 5 } & Energi (kkal) & Protein $(\mathbf{g})$ & Lemak $(\mathbf{g})$ & Karbohidrat $(\mathbf{g})$ \\
\hline 1 & 751 & 16,6 & 7,2 & 152,1 \\
2 & 382 & 10,6 & 4,6 & 75,2 \\
3 & 742 & 19,0 & 8,6 & 145,5 \\
4 & 416 & 15,0 & 7,5 & 73,6 \\
\hline Rata-rata & 573 & 15,3 & 7,0 & 111,6 \\
\hline
\end{tabular}

Sumber : Data Primer 2019

Tabel 4. Diketahui ketersediaan energi tertinggi pada hari pertama, ketersediaan protein tertinggi yaitu pada hari ketiga, ketersediaan lemak tertinggi pada hari ketiga, dan ketersediaan karbohidrat tertinggi pada hari pertama.

Perbandingan ketersediaan menu makan siang dengan rata rata kecukupan zat gizi (energi, protein, lemak,dan karbohidrat) dapat dilihat sebagai berikut.

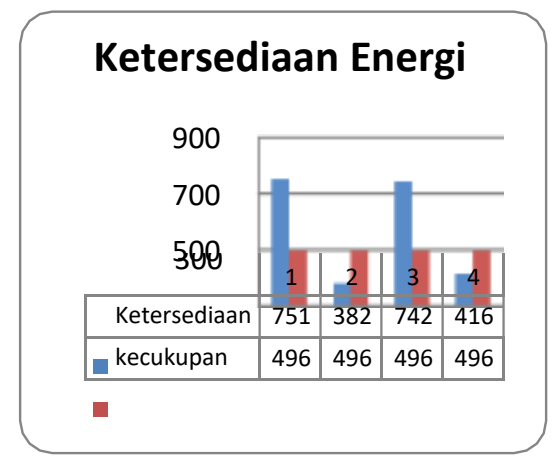

Diagram 2. Rata-rata tingkat ketersediaan energi

Dari diagram 2 di atas, diketahui bahwa rata-rata ketersediaan energi pada hari pertama dan ketiga melebihi dari rata rata kecukupan energi sedangkan pada hari kedua dan keempat kurang dari rata-rata kecukupan energi.

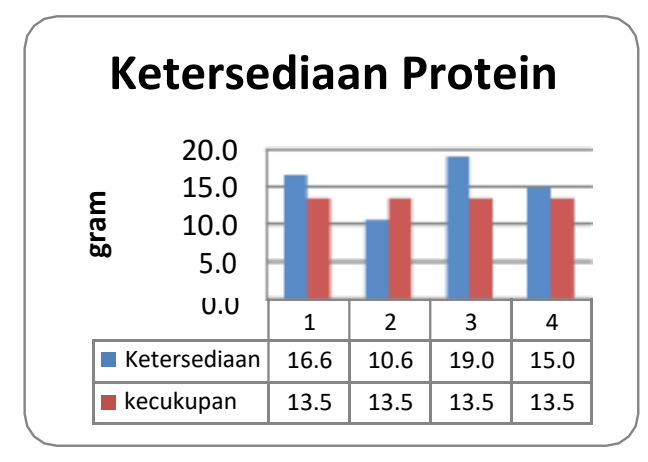

\section{Diagram 3. Rata-rata tingkat ketersediaan protein}

Pada diagram 3, diketahui bahwa rata-rata ketersediaan protein diatas rata-rata dari kecukupan protein. 


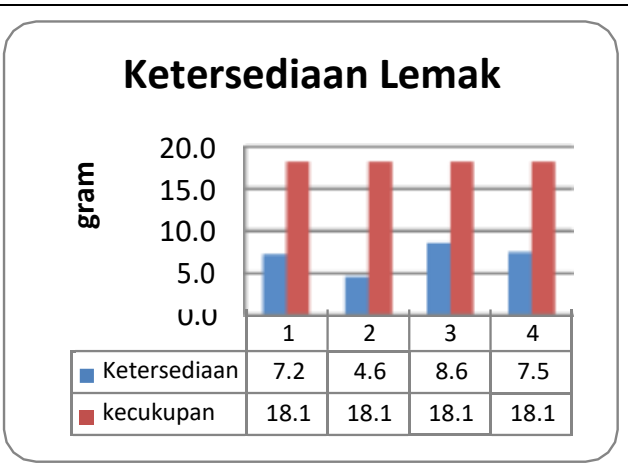

Diagram 4. Rata-rata Tingkat ketersediaan lemak

Pada diagram 4, diketahui bahwa rata-rata ketersediaan lemak selama 1 siklus menu kurang dari rata-rata kecukupan.

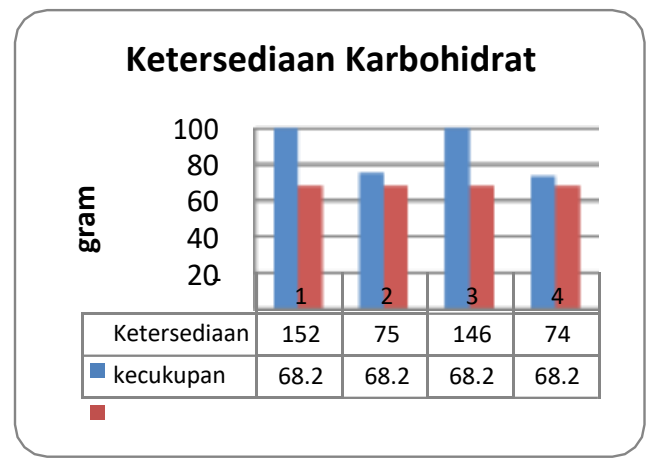

Diagram 5. Rata-rata Tingkat ketersediaan karbohidrat

Pada diagram 5, diketahui bahwa rata-rata ketersediaan karbohidrat selama 1 siklus menu, hari pertama dan kedua melebihi rata-rata kecukupan dan pada hari kedua dan keempat sudah sesuai dengan rata-rata kecukupan karbohidrat.

Ketersediaan zat gizi makro (Energi, Protein, Lemak, dan Karbohidrat) terhadap Kecukupan zat gizi anak sekolah.

Pada proses perencanaanmenu penyelenggaraan makanan anak sekolah, pertama-tama yang harus diperhatikan adalah kecukupan gizi siswa (Sinaga 2007). Kecukupan gizi (Energi, protein, lemak, dan karbohidrat). Untuk lebih lengkap dapat dilihat pada tabel berikut :

Tabel 5. Ketersediaan zat gizi makro pada menu makan siangterhadap kecukupan anak sekolah

\begin{tabular}{|c|c|c|c|c|c|c|c|c|}
\hline \multirow{3}{*}{ Tingkat kecukupan } & \multicolumn{8}{|c|}{ Ketersediaan } \\
\hline & \multicolumn{2}{|c|}{ Energi } & \multicolumn{2}{|c|}{ Protein } & \multicolumn{2}{|c|}{ Lemak } & \multicolumn{2}{|c|}{ Karbohidrat } \\
\hline & $\mathbf{n}$ & $\%$ & $\mathbf{n}$ & $\%$ & $\mathbf{n}$ & $\%$ & $\mathbf{n}$ & $\%$ \\
\hline Lebih & 98 & 45,4 & 101 & 46,8 & 0 & 0,0 & 151 & 69,9 \\
\hline Cukup & 54 & 25.0 & 63 & 29,2 & 2 & 0,9 & 47 & 21,8 \\
\hline Kurang & 64 & 29,6 & 52 & 24,1 & 214 & 99,1 & 18 & 8,3 \\
\hline Total & 216 & 100.0 & 216 & 100,0 & 216 & 100,0 & 216 & 100,0 \\
\hline
\end{tabular}

Sumber : Data Primer 2019

Pada tabel 5. Diketahui bahwa Ketersediaan energi berdasarkan kecukupan anak sekolah dalam pada kategori lebih sebanyak 98 orang $(45,4 \%)$, pada kategori cukup sebanyak 54 orang $(25,0 \%)$, dan pada kategori kurang sebanyak 64 orang $(29,6 \%)$. Ketersediaan zat gizi protein berdasarkan kecukupan anak sekolah pada kategori lebih sebanyak 101 orang (46,8\%), pada kategori cukup sebanyak 63 orang $(29,2 \%)$, 
dan kategori kurang sebanyak 52 orang $(24,1 \%)$. Ketersediaan zat gizi lemak berdasarkan dalam paling banyak pada kategori kurang sebanyak 214 orang $(99,1 \%)$, dan paling sedikit pada kategori cukup sebanyak 2 orang $(0,9 \%)$ Ketersediaan zat gizi karbohidrat pada kategori lebih sebanyak 151 orang $(69,9 \%)$, dan pada kategori kurang sebanyak 18 orang $(8,3 \%)$.

\section{PEMBAHASAN}

\section{Karakteristik Sampel}

Umur

Sampel yang digunakan dalam penelitian ini dari umur 6-12 tahun, yaitu tersebar dari kelas 1 sampai kelas 6 . Dapat dilihat bahwa bagian terbesar sampel (55\%) yaitu berumur 7-9 tahun, dan sampel terkecil usia 6 tahun (3\%). Usia termuda adalah 6 tahun dan usia tertua adalah 12 tahun.Kecukupan energi pada umur 10 - 12 tahun lebih besar dibanding golongan umur 7-9 tahun, ini karena pertumbuhan mereka lebih cepat, terutama penambahan berat badan. Mulai umur 10 - 12 tahun (As'ad, 2002). Kecukupan zat gizi pada umur 10 - 12 tahun lebih besar dibanding golongan umur 7-9 tahun, ini karena pertumbuhan mereka lebih cepat, terutama penambahan berat badan. Mulai umur 10 - 12 tahun (As'ad, 2002).

\section{Jenis Kelamin}

Distribusi jenis kelamin siswa sekolah dasar islam terpadu (SD IT) Insan Mulia Kediri menunjukkan jumlah anak laki-laki lebih banyak dibanding anak perempuan yaitu $52 \%$ banding $48 \%$. Anak laki-laki lebih banyak melakukan aktivitas fisik, sehingga memerlukan energi yang lebih banyak dari anak perempuan (As'ad, 2002).

\section{Biaya Menu Makan Siang}

Pihak Sekolah merencanakan anggaran untuk makan siang sebesar Rp5.000/siswa per hari. Diketahui bahwa biaya yang tertinggi dikeluarkan untuk penyelenggaran makanan yaitu pada hari ketiga Rp. 6.002 (120\% dari anggaran perhari) dan paling rendah pada hari kedua sebesar Rp 2.106 (29,1\% dari anggaran perhari). Ratarata biaya bahan pangan (food costs) yang dikeluarkan selama 1 siklus menu oleh pihak katering sebesar Rp 3501 atau sebesar 70\% dari keseluruhan biaya. Sisanya digunakan sebagai biaya overhead sehingga anggaran Rp 5.000/hari sudah sesuai. Biaya overhead yang dimaksud meliputi biaya-biaya alat, transportasi, dan profit.

Biaya pada hari pertama tinggi karena terdapat lauk hewani, yaitu daging sapi yang harganya cukup mahal. Biaya yang tinggi pada hari pertama sesuai dengan tingkat ketersediaan energi dan karbohidrat paling tinggi pada hari pertama. Dan biaya paling rendah terdapat pada hari kedua, ini mempengaruhi ketersediaan energi, protein, dan lemak pada hari kedua yang paling rendah selama 1 siklus menu.

Sejalan dengan hasil uji SPPS Spearman menunjukkan adanya hubungan antara biaya makan dengan ketersediaan energi, protein, lemak, dan Karbohidrat yaitu 0,00 ( $\mathrm{p}<0,05)$. Pada penelitian Fitri Asy Sifa (2016) bahwa menggunakan uji korelasi spearman, menunjukkan adanya hubungan antara biaya makan dengan ketersediaan energi, protein, lemak dan karbohidrat (nilai $\mathrm{p}<0.05$ ).

Dari hasil uji korelasi bivariat dilakukan diketahui bahwa, terdapat hubungan yang signifikan antara biaya makan dengan ketersediaan energi, protein, lemak, dan karbohidrat. Dapat diartikan bahwa semakin tinggi biaya makan yang digunakan oleh pihak penyelenggaraan menu makan siang di SDIT Insan Mulia Kediri, maka ketersediaan energi, protein, lemak dan karbohidrat makanan yang disediakan akan lebih tinggi nilainya.

\section{Pola Menu}

Pola menu pada hari pertama paling tinggi menyumbangkan ketersediaan Energi dan Karbohidrat. Pola menu hari pertama terdapat, makanan pokok, daging sapi dan sayur. Pola menu pada hari ketiga mirip dengan pola hari pertama dengan tambahan lauk nabati sehingga pada hari ketiga menyumbangkan protein dan lemak paling tinggi (19,6\% dan 8,8\%). Sedangkan pada hari kedua menyumbangan energi, protein, lemak, paling rendah dengan pola menu makanan pokok, lauk nabati, dan sayur. Pola menu hari kedua dan keempat mirip, hanya pada pola menu hari keempat terdapat 2 jenis lauk nabati yaitu tahu dan tempe sehingga lebih banyak menyumbangkan ketersediaan energi, protein dan lemak dibanding hari kedua.

Pola menu di yang ada di SDIT Insan Mulia Kediri kurang bervariasi, lauk nabati yang sering muncul adalah tempe dan lauk hewani adalah bakso serta tidak terdapat sayur pada hari pertama dan ketiga. Pola menu 
untuk makan siang terdiri atas makanan pokok, lauk (hewani dan nabati), dan sayur. Selama 1 siklus menu, hari pertama dan ketiga paling kurang menurut jenisnya, karena tidak ada sayur.

Data SUSENAS tahun 2004 mencatat bahwa 60,44\% masyarakat Indonesia kurang mengkonsumsi sayur dan buah. Di temukan bahwa 56,6\% anak sekolah tidak mau mengkonsumsi sayuran. Bagi orang Indonesia dianjurkan konsumsi sayuran dan buah-buahan 300-400 g perorang perhari bagi anak usia sekolah. Menurut panduan umum gizi seimbang (PUGS ) susunan hidangan harus terdiri dari nasi, lauk, sayur dan buah-buahan yang secara alamiah (pedoman gizi seimbang, 2014).

\section{Ketersediaan menu makan siang yang disediakan di SD IT Insan Mulia Kediri}

Menurut Nacing (2007) menyatakan bahwa keadaan gizi seseorang secara langsung dipengaruhi oleh ketersediaan zat-zat gizi dalam jumlah dan mutu yang cukup untuk memenuhi kecukupan. Ketersediaan zat gizi yang kurang akan menyebabkan kecukupan gizi pada siswa kurang, atau sebaliknya. Makanan yang disediakan oleh sekolah atau pihak penyelenggara makanan harus terdiri dari sumber utama dari ketersediaan energi, protein, lemak,dan karbohidrat.

Ketersediaan menu makan siang yang disajikan di SDIT Insan Mulia Kediri berbeda beda tiap hari. ketersedian energi paling tinggi pada hari pertama sebesar 751 kkal (151\%) sedangkan rata-rata kecukupan energi seharusnya 496 kkal. Dan ketersediaan paling sedikit pada hari kedua 407 kkal (81,9\%). Ketersediaan energi dan lemak paling rendah. Pada hari kedua energi sebesar $78 \%$ dan lemak 25\%, hanya menyumbangkan energi sebesar $382 \mathrm{kkal}$ dan lemak 4,6 gram. pola menu hari kedua terdiri dari makanan pokok, lauk nabati, dan sayur. Tidak ada sumber lemak dan pengolahan menggunakan minyak hanya pada lauk nabati yaitu tempe manis sehingga menyumbangan lemak paling rendah. Ketersediaan protein paling tinggi pada hari ketiga sebesar 19 gram (141\%) dan paling rendah pada hari kedua sebesar 10,6 gram (78\%) termasuk normal. Hasil ketersediaan protein di SDIT Insan Mulia Kediri lebih tinggi dibanding Rata-rata tingkat ketersediaan protein yaitu 89.09\% dengan tingkat ketersediaan protein pada penelitian Fitri Asy Syifa (2016)

Hasil Uji korelasi pearson yang dilakukan terdapat hubungan yang siginifikan antara ketersediaan dengan tingkat kecukupan. Ini bisa diartikan bahwa semakin tinggi ketersediaan zat gizi yang disediakan semakin tinggi juga kecukupan gizi anak sekolah, dan sebaliknya. Ketersediaan zat gizi pada menu makan siang harus sesuai dengan kecukupan anak. ketersediaan energi pada menu makan siang yang disajikan berdasarkan kecukupan zat gizi anak sekolah dalam paling banyak pada kategori lebih sebanyak 98 orang $(45,4 \%)$. Penelitian yang telah dilakukan oleh Yamin (2013) menunjukkan bahwa tingkat kecukupan energi dan karbohidrat yang cukup sampai dengan tinggi, akan menyebabkan obesitas pada siswa di Manado (Yamin B, Mayulu N, \& Rottie J. 2013). Hal tersebut disebabkan karena ketika asupan energi yang masuk kedalam tubuh melebihi yang dibutuhkan, maka kelebihan asupan tersebut oleh tubuh akan disimpan menjadi lemak di jaringan adipose (Sulistyoningsih,2011).

Dari penelitian Suryandari dan Widyastuti (2015) tentang hubungan asupan protein dan obesitas, diketahui bahwa adanya hubungan yang signifikan asupan protein dengan obesitas. Kekurangan asupan protein juga sangat berbahaya, apabila asupan protein terlalu rendah dapat merugikan karena protein tubuh akan dipecah dan tenaga akan dipakai untuk melakukan pemecahan protein tubuh tersebut dan apabila kelebihan asupan protein juga dapat menyebabkan terbentuknya lemak tubuh dan meningkatnya kebutuhan akan air (Fatmah 2011). Asupan protein kurang dapat berpengaruh pada penghambatan pertumbuhan anak karena fungsi utama protein adalah sebagai pembentuk jaringan baru pada masa pertumbuhan dan perkembangan tubuh, memelihara dan memperbaiki, serta mengganti jaringan tubuh yang rusak atau mati. Ketersediaan lemak pada menu makan siang yang disajikan berdasarkan kecukupan zat gizi anak sekolah paling banyak pada kategori kurang sebanyak 214 orang $(99,1 \%)$, ini sejalan dengan hasil penelitian Nur Safira Anindita (2017) Rata-rata tingkat kecukupan lemak yang sajikan sebagian besar dikatagorikan defisit berat yaitu sebanyak 96.8\%. Rendahnya tingkat kecukupan lemak disebabkan oleh jumlah ketersediaan menu makan siang yang mengandung lemak masih kurang dari kecukupan. ini sejalan dengan hasil uji korelasi yang dilakukan terdapat signifikan atau hubungan antara kecukupan lemak dengan ketersediaan lemak 0,00 ( $\mathrm{p}<0,05)$. Kinanthi (2011) menyatakan bahwa asupan lemak kurang dapat menjadi faktor risiko pada anak stunting karena pada anak yang memiliki TB/U kurang dari -2 SD dapat menganggu keseimbangan metabolisme penyerapan zat gizi pada tubuh yang berlanjut pada usia remaja. 


\section{KESIMPULAN}

Berdasarkan hasil dari kesimpulan diketahui bahwa secara umum rata rata ketersediaan energi, protei, lemak sudah memenuhi kecukupan gizi kecuali lemak. Terdapat hubungan yang signifikan antara ketersediaan zat gizi makro dengan kecukupan gizi anak sekolah yaitu $0,00(\mathrm{p}<0,05)$, sehingga semakin tinggi ketersediaan zat gizi makro yang disediaakan semakin tinggi juga kecukupan gizi anak sekolah yang dapat terpenuhi.

\section{SARAN}

Berdasarkan hasil penelitian diperlukan evaluasi menu makan siang yang disajikan di SDIT Insan Mulia Kediri berdasarakan kecukupan gizi anak sekolah, pola menu, dan biaya

\section{DAFTAR PUSTAKA}

As'ad,S. 2007. Gizi Kesehatan Ibu dan Anak. Proyek peningkatan pendidikan tertinggi. Jakarta : Depertemen Pendidikan Nasional.

Depkes RI. 2015. Pedoman Perbaikan Gizi Anak Sekolah Dasar, dan Madrasah Ibtidaiyah. Jakarta: Direktorat Gizi Masyarakat.

Fatmah. Ruhayati Y. 2011. Gizi kebugaran dan olahraga. Jawa Barat (ID): Lubuk Agung

Kementerian Kesehatan Republik Indonesia.2013. Riset Kesehatan Dasar.. Riskesdas Kemenkes RI. Jakarta. Kementerian Kesehatan Republik Indonesia. 2017. Hasil pemantauan status gizi tahun 2017 dan penjelasannya. Direktorat Gizi Masyarakat Direktorat Jenderal Kesehatan Masyarakat Kementerian Kesehatan.

Kementerian Kesehatan Republik Indonesia. 2014. Pedoman Gizi Seimbang. Direktorat Jenderal Bina Gizi dan KIA. Jakarta. Halm 12-22

Kinanthi, SH. 2008. Faktor Risiko Kejadian Overweight pada Anak Stunting Usia Sekolah Dasar di Semarang Timur [Skripsi]. Fakultas Kedokteran, Universitas Diponegoro. Semarang.

Notoatmodjo, Soekidjo. 2010. Metodologi Penelitian Kesehatan. Edisi Revisi Cetakan Pertama. Rineka Cipta. Jakarta

Sifa, Asy Sifa. 2016. Biaya makan, ketersediaan energi dan zat gizi serta tingkat kecukupan gizi mahasiswa dipenyelenggaraan makanan asrama [skripsi]. Departemen gizi masyarakat fakultas ekologi manusia institut pertanian Bogor.

Suryandari,Beti dan Widyastuti. 2015. Hubungan Asupan Protein dengan obesitas pada remaja. Program Studi Gizi Universitas Diponegoro : Semarang

Sulistyioningsing, Haryani. 2011. Gizi untuk kesehatan ibu dan anak. Graha Ilmu. Yogyakarta. Yamin B, Mayulu N, \& Rottie J. Hubungan Asupan Energi Dengan Kejadian Obesitas Pada Siswa.

Utami, Adina Tri. 2013. Studi Evaluasi Penyelenggaraan Makan Siang Di Sekolah Dasar Islam Ulil Albab Kabupaten Kebumen.Skripsi Pendidikan Teknik Boga Fakultas Teknik Universitas Negeri Yogyakarta

Sekolah Dasar Di Kota Manado. Ejournal Keperawatan, 2013;1(1): p. 1-8. Available from https://ejournal.unsrat.ac.id/index.php/jkp/article/view/2165/1723 Diakses pada 17 Maret 2017 